\title{
IDENTICAL POLYPYRIMIDINE-POLYPURINE SATELLITE DNAs IN WHEAT AND BARLEY
}

\author{
E. S. DENNIS, W. L. GERLACH and W. J. PEACOCK \\ Division of Plant Industry, Commonwealth Scientific and Industrial Research Organisation, \\ P.O. Box 1600, Canberra City, A.C.T. 2601, Australia
}

Received 17.ix.79

\section{SUMmary}

\begin{abstract}
A satellite DNA can be isolated from wheat and barley using $\mathrm{Ag}^{+} / \mathrm{Cs}_{2} \mathrm{SO}_{4}$ gradients. These DNAs are highly repeated, each with a complexity of about $10 \mathrm{bp}$. The satellites isolated from the two species cannot be differentiated by physical properties such as buoyant density, melting temperature or renaturation kinetics and heterologous hybrids melt at the same temperature as homologous hybrids. The restriction endonuclease MboII digests both satellites to give identical patterns. These data together with those from digests of RNAs complementary to the separated DNA strands suggest a general formulation of a sequence as $(\mathrm{GAA})_{m}(\mathrm{GAG})_{n}$. Localisation of the satellite by in situ hybridisation shows it to have major sites on all seven chromosomes of the $\mathrm{B}$ genome and chromosomes $4 \mathrm{~A}$ and $7 \mathrm{~A}$ in hexaploid wheat, and on all barley chromosomes. There are specific minor sites on other chromosomes of the $\mathrm{A}$ and $\mathrm{D}$ genomes of wheat.
\end{abstract}

\section{INTRODUCTION}

REGent data on the properties of highly repeated DNAs have challenged the previously held concepts of the gross instability of such sequences during evolution (Walker, 1968; Hennig and Walker, 1970). A comparison of the sequence of the HS- $\alpha$ satellite of Dipodomys ordii with that of satellite DNAs from different rodent species led Salser et al. (1976) to propose that rodents may share a common library of sequences which are maintained over long evolutionary times but which vary in amount between species (Fry and Salser, 1977). This contrasts with the suggestion that these sequences have arisen relatively recently (Southern, 1970). Support for the "library concept" is found in the data of Gall and Atherton (1974) who showed that the nucleotide sequence of a satellite DNA from Drosophila virilis was identical to that of one isolated from the sibling species $D$. americana. Additional support comes from a comparison of the satellite DNAs of $D$. melanogaster and D. simulans (Peacock et al., 1976, Lohe, 1977). These studies showed that the same highly repeated DNA sequences were present in both Drosophila species and, relative to the other reiteration classes of DNA, showed conservation of nucleotide sequence. However the amount of any particular highly repeated sequence differed greatly between the two species but chromosomal locations were maintained.

We report the isolation of a satellite DNA from each of the genomes of wheat and barley and show that in these plants the basic repeating sequence is conserved although the absolute amount of the satellite in the genome differs in these two (and other) species. This is a situation comparable to the animal kingdom examples described above. Other properties 
in common with animal species are multi-chromosomal occurrence, and specificity of chromosomal distribution pattern.

\section{MAterials AND METHODS}

(i) Species used

Wheat: Triticum aestivum var. Chinese Spring $(2 \mathrm{n}=6 \mathrm{x}=42$ Genome constitution AABBDD)

Aegilops squarrosa $(2 \mathrm{n}=2 \mathrm{x}=14, \mathrm{DD})$

Triticum monococcum $(2 \mathrm{n}=2 \mathrm{x}=14, \mathrm{AA})$

Barley: Hordeum vulgare var. Clipper $(2 \mathrm{n}=2 \mathrm{x}=14)$

\section{(ii) Isolation of $D \mathcal{N A}$}

DNA was isolated from shoots of one-week-old seedlings grown in vermiculite in the dark. Shoots were cut, frozen in liquid nitrogen and ground to a powder. Buffer $(0 \cdot 15 \mathrm{M} \mathrm{NaCl}, 0 \cdot 1 \mathrm{M}$ EDTA $\mathrm{pH} 8)$ and sodium lauryl sulphate $(0.8$ per cent $\mathrm{w} / \mathrm{v})$ were added, the suspension heated to $60^{\circ}$ for $10 \mathrm{~min}$, pronase (Sigma) $(0.04$ per cent $\mathrm{w} / \mathrm{v})$ added and incubation continued for $30 \mathrm{~min}$ at $41^{\circ} \mathrm{C}$. The suspension was made $0.55 \mathrm{M} \mathrm{NaCl}$, centrifuged at low speed to remove particulate material and extracted with an equal volume of phenol. The phenol layer was re-extracted and the nucleic acid was precipitated from the pooled aqueous fractions. RNase A (Sigma, $10 \mu \mathrm{g} / \mathrm{ml}, 37^{\circ} \mathrm{C}, 30 \mathrm{~min}$ ) treatment followed resuspension of the DNA in $2 \times \mathrm{SSC}$ (SSC is $0.15 \mathrm{M} \mathrm{NaCl}, 0.015 \mathrm{~m}$ sodium citrate). The DNA was again precipitated with two volumes of ethanol and further purified by centrifugation in a $\mathrm{CsCl}$ buoyant density gradient. DNA was stored in TE $\left(10 \mathrm{~mm}\right.$ Tris- $\mathrm{HCl}, 1 \mathrm{mM}$ EDTA, $\mathrm{pH}=8 \cdot 4$ ) at $4^{\circ} \mathrm{C}$.

\section{(iii) Ultracentrifugation}

\section{(a) $\mathrm{Ag}^{+} / \mathrm{Cs}_{2} \mathrm{SO}_{4}$ buoyant density gradients}

For analytical ultracentrifugation $250 \mu \mathrm{l}$ native DNA $(120 \mu \mathrm{g} / \mathrm{ml}$ in TE) was mixed with $150 \mu \mathrm{l} 25 \mathrm{~mm}$ borate buffer $\left(50 \mathrm{~mm} \mathrm{Na} \mathrm{SO}_{4}, 25 \mathrm{~mm}\right.$ $\mathrm{Na}_{2} \mathrm{~B}_{4} \mathrm{O}_{7}, \mathrm{pH}=9 \cdot 1$ ). Whilst vortexing, $\mathrm{AgNO}_{3}$ was added dropwise until the desired $R_{F}$ was achieved $\left(R_{F}=\right.$ mole ratio of silver ions to DNA phosphate). Samples were then made to a final volume of $650 \mu \mathrm{l}$ with $\mathrm{H}_{2} \mathrm{O}$, and $\mathrm{Cs}_{2} \mathrm{SO}_{4}$ (Merck) added to the required density (usually in the range 1.48 to $\left.1.53 \mathrm{gm} / \mathrm{cm}^{3}\right)$. Samples were centrifuged to equilibrium in a Beckman Model $\mathrm{E}$ ultracentrifuge $\left(44,000 \mathrm{rpm}, 25^{\circ} \mathrm{C}\right)$ equipped with a photoelectric scanner.

For preparative isolation of satellite DNA, samples were made according to conditions which showed separation of satellite from main band DNA on analytical ultracentrifugation. $18 \mathrm{ml}$ samples were centrifuged to equilibrium (Beckman L3-50 centrifuge, $20^{\circ} \mathrm{C}$ ) and fractions collected from the bottom of the gradients. Fractions containing satellite DNA were located by absorbance at $260 \mathrm{~nm}$, pooled, and dialysed against TE. It was found that DNA isolated in this way was contaminated with material which showed a strong absorbance at $250 \mathrm{~nm}$. This was removed by ethanol precipitation of the DNA from a sodium perchlorate $\left(\mathrm{NaClO}_{4}\right)$ solution; 
the DNA was made $5 \mathrm{M}$ with $\mathrm{NaClO}_{4}$ and precipitated by adding 2 volumes ethanol and $0 \cdot 1$ volume $3 \mathrm{~m}$ sodium acetate, $\mathrm{pH}=5 \cdot 5$. The DNA was isolated by centrifugation and resuspended in TE.

\section{(b) $\mathrm{CsCl}$ buoyant density gradients}

For neutral CsGl gradients, CsCl (Merck) was added to DNA in TE to a density of $1.700-1 \cdot 710 \mathrm{gm} / \mathrm{cm}^{3}$. For alkaline gradients, $\mathrm{CsCl}$ was added to DNA (in $0.1 \mathrm{~N} \mathrm{NaOH}$ in TE) to a density of $1.760 \mathrm{gm} / \mathrm{cm}^{3}$. Micrococcus luteus DNA was used as marker in analytical centrifugation; density = 1.731 and $1.789 \mathrm{gm} / \mathrm{cm}^{3}$ in neutral and alkaline gradients respectively.

\section{(iv) Thermal denaturation profles}

DNA samples to be melted were co-dialysed for 24 hours with native Escherichia coli DNA (Sigma) against TE. Optical melting curves at $260 \mathrm{~nm}$ were obtained using a Gilford recording spectrophotometer. The temperature was raised by a Haake ethylene glycol bath at a rate of either $45^{\circ} \mathrm{C}$ or $60^{\circ} \mathrm{G}$ per hour. The $E$. coli DNA was included in a second cuvette in each experiment as an internal control; the melting temperature of the sample was adjusted relative to a standard melting temperature for $E$. coli DNA of $65.8^{\circ} \mathrm{C}$ in TE.

\section{(v) Renaturation analysis}

DNA for renaturation $\left(20 \mu \mathrm{g} / \mathrm{ml}\right.$ in $0.1 \times \mathrm{SSC}$ or $\left.0.02 \mathrm{M} \mathrm{Na}{ }^{+}\right)$was sheared by sonication $(3 \times 30 \mathrm{sec}$ treatments, maximum output, Branson B-12 Sonifier fitted with microprobe) and loaded into jacketed quartz spectrophotometer cells. The cells were placed in a Varian Techtron 635 spectrophotometer and connected to an externally regulated temperature water bath. The temperature of the circulating water was increased at a rate of $1^{\circ} \mathrm{C} / \mathrm{min}$ to $90^{\circ} \mathrm{C}$ to melt the DNA and was then immediately changed to $40^{\circ} \mathrm{C}$ to initiate renaturation. This corresponds to approx. $\mathrm{T}_{m}-25^{\circ}$ for the satellite DNA in this salt concentration. Temperature equilibration occurred within 30 secs using this technique. The change in optical density at $260 \mathrm{~nm}\left(\mathrm{OD}_{260}\right)$ of the sample was continuously monitored. Renaturation was carried out in $0.1 \times \mathrm{SSC}$ or in $0.02 \mathrm{M} \mathrm{Na}+$ to lower the reassociation rate to a level which could be accurately monitored by this technique.

$\mathrm{C}_{\mathrm{o}}$ t values were not corrected to standard conditions because the dependence of the renaturation rate of repeated DNA upon salt concentration or length is not understood.

\section{(vi) Preparation of $c R \mathcal{N A}$}

${ }^{3} \mathrm{H}$-labelled cRNA (RNA complementary to a DNA template) was prepared using $E$. coli $\mathrm{RNA}$ polymerase in an in zitro reaction. The reaction mixture contained 4 $\mu \mathrm{g}$ DNA template, ${ }^{3} \mathrm{H}$-labelled GTP, CTP, UTP (6-7 $\times 10^{-3} \mu$ moles each) obtained from The Radiochemical Centre, Amersham, $10^{-1} \mu$ moles ATP and $E$. coli RNA polymerase (prepared according to Burgess and Jendrisak, 1975) in $100 \mu \mathrm{l}$ of a buffer which was $0.04 \mathrm{M}$ Tris- $\mathrm{HCl} \mathrm{pH} \mathrm{7.9,0.01} \mathrm{M} \mathrm{MgCl}_{2}, 0.16 \mathrm{M} \mathrm{KGl}$ and $2 \times 10^{-4} \mathrm{M}$ dithiothreitol at $37^{\circ} \mathrm{C}$. After $2-3$ hours the template was removed by DNase treatment (Worthington DPFF, $100 \mu \mathrm{g} / \mathrm{ml}, 30 \mathrm{~min}$ ) and the product isolated by phenol 
extraction, G-75 Sephadex chromatography and ethanol precipitation. It was redissolved in $6 \times \mathrm{SSC}$ solution and stored at $-20^{\circ} \mathrm{C}$.

$\alpha$-32P-labelled ribonucleoside- 5 '-triphosphates were used for the synthesis of ${ }^{32} \mathrm{P}$-labelled cRNA. The individual triphosphates were prepared according to Symons (1974).

(vii) In situ hybridisation

To accumulate root tip metaphases 3 -day-old seedlings grown at $27^{\circ} \mathrm{C}$ were treated with 0.025 per cent colchicine for 3 hours prior to fixation in $1: 3$ acetic ethanol. Root tip squashes were prepared in 45 per cent acetic acid, dehydrated in absolute alcohol and air dried before use. Chromosomal DNA was denatured by incubation in $0.2 \mathrm{~N} \mathrm{HCl}$ at $37^{\circ} \mathrm{C}$ for $30 \mathrm{~min}$, followed by dehydration through an alcohol series and air drying. $5 \mu$ l of cRNA in $3 \times \mathrm{SSC}$, 50 per cent formamide $\left(10^{4}-10^{5} \mathrm{cpm} / \mu \mathrm{l}\right)$ was placed on each slide, covered with an $18 \mathrm{~mm}^{2}$ cover slip and sealed with rubber gum. The preparations were heated to $70^{\circ} \mathrm{C}$ for 30 seconds to ensure that all chromosomal sites were available for hybridisation (after Singh et al., 1977) and then incubated for 3 hours at $45^{\circ} \mathrm{C}$ to effect hybridisation. Cover slips were removed and slides were washed twice in $3 \times \mathrm{SSC}, 50$ per cent formamide $\left(10 \mathrm{~min}\right.$ each wash, $\left.45^{\circ} \mathrm{C}\right)$ before RNAase treatment $(2 \mu \mathrm{g} / \mathrm{ml} \mathrm{Sigma}$ pancreatic RNAase and 1.25 units of Calbiochem $\mathrm{T}_{1}$ RNAase in $2 \times \mathrm{SSC}$, $30 \mathrm{~min}$ at $37^{\circ} \mathrm{C}$ ). Following further washes in $2 \times \mathrm{SSC}(6$ washes, $10 \mathrm{~min}$ each) the slides were ethanol dehydrated, air dried and coated with Ilford $\mathrm{K} 2$ emulsion (50 per cent dilution). Exposures were 4-6 days. Slides were stained with 1 per cent Gurr's Giemsa in $0.02 \mathrm{M}$ phosphate buffer ( $\mathrm{pH} 6 \cdot 8$ ).

Telocentric strains of Chinese Spring wheat, which each have one particular chromosome pair present as recognisable double or single telocentrics, were used to identify the heavily labelled chromosomes. These strains were originally produced by E. Sears and were a gift from K. Shepherd, Waite Agricultural Research Institute.

\section{(viii) Alkaline hydrolysis of $c R \mathcal{N A s}$ and base compositions of complementary strands}

The complementary strands of the satellite were isolated and purified in alkaline $\mathrm{CsCl}$ buoyant density gradients. Uniformly ${ }^{32} \mathrm{P}$-labelled cRNAs were prepared using ${ }^{32}$ P-labelled UTP, CTP, ATP and GTP on each strand as template. The base compositions were determined in duplicate by hydrolysing the cRNA with piperidine ( 10 per cent Fluka piperidine, $100^{\circ} \mathrm{C}, 2 \mathrm{hrs}$ ) and fractionating the ${ }^{32} \mathrm{P}$-labelled nucleoside monophosphate products on Whatman $3 \mathrm{MM}$ paper by high voltage electrophoresis at $\mathrm{pH}=3.5$ as described by Brownlee (1972).

\section{(ix) Complete ribonuclease digestions of $c R \mathcal{N} A$ s and fractionation of products}

Uniformly ${ }^{32} \mathrm{P}$-labelled cRNAs prepared from each of the satellite strands were digested either with pancreatic or $T_{1}$ ribonuclease. Reaction mixtures contained cRNA, $20 \mu \mathrm{g}$ unlabelled yeast RNA and 0.5 $\mu \mathrm{g}$ Sigma ribonuclease $\mathrm{A}$ or 5 units Calbiochem $\mathrm{T}_{1}$ ribonuclease in $10 \mu \mathrm{l} 0.01 \mathrm{~m}$ Tris-HCl, $\mathrm{pH}=7 \cdot 4$. Following digestion at $37^{\circ} \mathrm{C}$ for 1 hour, reaction mixtures were 
made $0.1 \mathrm{~N}$ with $\mathrm{HCl}$ and incubated at $37^{\circ} \mathrm{C}$ for a further $30 \mathrm{~min}$ to break down cyclic phosphates. The resultant oligonucleotides were separated by two-dimensional ascending chromatography on $20 \times 20 \mathrm{~cm}$ Polygram cell $300 \mathrm{PEI} / \mathrm{UV}_{254}$ TLC plates (Machery-Nagel and Co.) using lithium formate, $\mathrm{pH} 3.4$ and lithium chloride, $\mathrm{pH} 8.0$, as the first and second dimension chromatography solvents (after Griffin and Mirzabekov, 1972). Oligonucleotide spots were detected by exposure of the chromatographs on $\mathrm{X}$-ray film and identified by isolating the oligonucleotides from the chromatographs, determining their composition and comparing that with the known migrations of defined oligonucleotides in the system (Griffin and Mirzabekov, 1972).

\section{(x) Estimation of $c R \mathcal{N} A$ lengths using formamide acrylamide gels}

The formamide-acrylamide gel electrophoresis technique was similar to that used by Symons (pers. comm.). 4.8 per cent acrylamide gels using formamide solvent were prepared as follows: $1.05 \mathrm{~g}$ of recrystallised acrylamide and $0.16 \mathrm{~g}$ of bis-acrylamide were added to $25 \mathrm{ml}$ formamide which had been previously deionised by stirring with equal amounts of Dowex 1 $\left(\mathrm{OH}^{-}\right)$and Dowex $50\left(\mathrm{H}^{+}\right)$. The solution was degassed and $55 \mu$ l tetramethylethylenediamine and $180 \mu l$ fresh 10 per cent ammonium persulphate added. $9 \mathrm{~cm}$ tube gels $(0.7 \mathrm{~mm}$ diam.) were poured and gently overlayed with 70 per cent aq. formamide. Gels were left for at least 4 hours to set.

RNA samples were loaded in a solution of 12.5 per cent sucrose in $0.2 \mathrm{M}$ $\mathrm{NaCl}$ in deionised formamide containing bromophenol blue dye to mark the running front. Loaded samples were overlayed with $0.2 \mathrm{M} \mathrm{NaCl}$ in deionised formamide. Electrode buffer was $0.2 \mathrm{M} \mathrm{NaCl}$ and electrophoresis was at $1 \mathrm{~mA} / \mathrm{gel}$ for 5 hours.

Molecular weight markers were $E$. coli 23S RNA (MW $\left.=1 \cdot 1 \times 10^{6} \mathrm{~d}\right)$, 16S RNA $\left(5.5 \times 10^{5} \mathrm{~d}\right)$ and 5S RNA $\left(4 \times 10^{4} \mathrm{~d}\right)$, wheat 4S RNA $\left(2.5 \times 10^{4} \mathrm{~d}\right)$ and TMV RNA $\left(2 \cdot 8 \times 10^{5} \mathrm{~d}\right)$. Amounts of these markers (approx. 4-10 $\mu \mathrm{g}$ / gel) were sufficient to show staining with 0.5 per cent toluidine blue in 5 per cent ethanol. To determine the migration of ${ }^{32} \mathrm{P}-$ labelled cRNA, gels were cut into $2 \mathrm{~mm}$ transverse sections on a Mickle Gel Slicer, the sections dried at $60^{\circ} \mathrm{C}$ and the radioactivity counted in a Nuclear Chicago Gas Flow Counter.

\section{(xi) Filter hybridisation experiments}

DNA was loaded onto prewashed Sartorius membrane filters according to the procedure of Birnstiel et al. (1972). For hybridisation, filters were first washed for 10 mins in $3 \times \mathrm{SSC}, 50$ per cent formamide at room temperature. Saturation hybridisation analyses were carried out by adding different amounts of ${ }^{3} \mathrm{H}$-cRNA to $0.2 \mathrm{ml} 3 \times \mathrm{SSC}, 50$ per cent formamide in glass vials. One $7.75 \mathrm{~mm}$ filter loaded with DNA and one blank filter was added to each vial. Hybridisation was carried out with gentle shaking at $45^{\circ} \mathrm{C}$ for 3 hours. If hybridisation mixtures were preheated, the vials containing the filters and hybridisation mixtures were incubated at $70^{\circ} \mathrm{C}$ for $3 \mathrm{~min}$ immediately prior to hybridisation. This was done to ensure that all cRNA was denatured and available for hybridisation. After hybridisation, filters were washed extensively with $3 \times \mathrm{SSC}$, 50 per cent formamide, treated with 
pancreatic and $T_{1}$ ribonuclease, dried and counted. Corrections were made for background radioactivity on the blank filters.

\section{(xii) Melting of hybrids from filters}

Hybridisation was carried out as described in the preceding section. After extensive washing and ribonuclease treatment the filters were placed in vials containing a known amount of $3 \times \mathrm{SSC}, 50$ per cent formamide. After 2 min at a particular temperature the filter was transferred to another vial at an increased temperature. The counts liberated at each temperature were measured, and the stability of the initial hybrids determined from a cumulative plot.

\section{(xiii) Nick-translation of $D \mathcal{N} A$}

Satellite DNA was ${ }^{32}$ P-labelled by nick translation (Rigby et al., 1976) using ${ }^{32} \mathrm{PdTTP}$ and $E$. coli DNA polymerase I.

\section{(xiv) Mbo II digests}

Mbo II restriction endonuclease (Gelinas et al., 1977) was a kind gift of Dr D. L. Brutlag. Satellite DNA, ${ }^{32}$ P-labelled by nick translation was digested with $\mathrm{Mbo}$ II in a buffer of $10 \mathrm{~mm}$ Tris pH 7.5, $7 \mathrm{~mm} \mathrm{MgCl}_{2} 6 \mathrm{~mm}$ $\mathrm{KCl}, 6 \mathrm{~mm} \beta$ mercaptoethanol. The Mbo II fragments were resolved by electrophoresis in a 20 per cent polyacrylamide $7 \mathrm{M}$ urea gel (Maxam and Gilbert, 1977) and detected by autoradiography. Nick translated Drosophila melanogaster 1.705 satellite DNA (Peacock et al., 1973) digested by Mbo II enzyme was always included as a standard. The $D$. melanogaster 1.705 satellite has the major sequence AAGAG (with a minor amount of AAGAGAG $)$ and is digested to a series of 5, 10, 15, 20 nucleotide long products by Mbo II (Endow, 1977; Brutlag et al., 1977).

\section{RESULTS}

(i) Isolation and physical characterisation of the cereal satellite $D \mathcal{N A}$

When total DNA of either wheat or barley is complexed with silver ions in a $\mathrm{Ag}^{+} / \mathrm{Cs}_{2} \mathrm{SO}_{4}$ buoyant density gradient, small proportions of the DNA are separated as satellite peaks (fig. 1). When the molar ratio of silver ions to phosphate residues is in the range $0 \cdot 075$ to $0 \cdot 125$ there is a clear separation of a satellite peak on the heavy side of the main band of DNA. We have isolated this satellite which in neutral $\mathrm{CsCl}$ gradients, has a single density peak of $1.699 \mathrm{~g} / \mathrm{cc}$ in wheat, and in barley shows a smaller amount of another DNA at $1.720 \mathrm{~g} / \mathrm{cc}$ as well as the $1.699 \mathrm{~g} / \mathrm{cc}$ component. It is the $1.699 \mathrm{~g} / \mathrm{cc}$ DNA present in both species which is examined in this paper.

The proportion of the satellite in each of the two genomes has been estimated from yields from total DNA (table 1). Both the wheat and barley $1.699 \mathrm{~g} / \mathrm{cc}$ satellites separate into two equimolar peaks in alkaline $\mathrm{CsCl}$ gradients (table 1). If the satellite DNA is denatured by heating, and reannealed, the density increases to $1.705 \mathrm{~g} / \mathrm{cc}$ indicating that there is approximately 5 per cent mismatching of base pairs in the reassociated molecules resulting from sequence heterogeneity in the native satellite. 


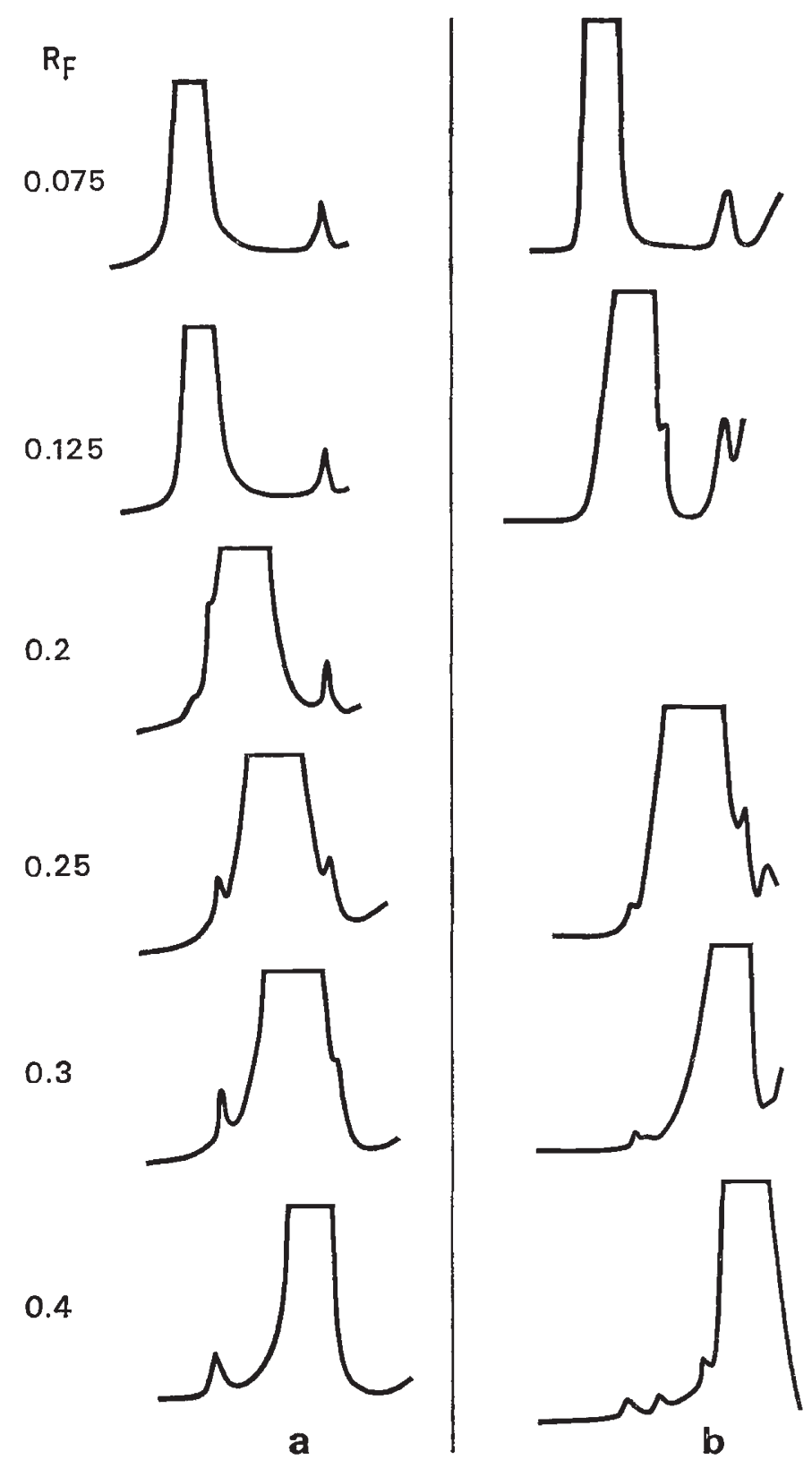

Fig. 1.-Analytical $\mathrm{Ag}^{+} / \mathrm{Cs}_{2} \mathrm{SO}_{4}$ density gradient centrifugation profiles of wheat (la) and barley (lb) DNA. The approximate molar ratio of $\mathrm{Ag}^{+}$to DNA $\left(\mathrm{R}_{\mathrm{F}}\right)$ is indicated in each of the diagrams. Density increases from left to right. 
TABLE 1

Comparison of the physical properties of the $1.699 \mathrm{~g} / \mathrm{cc}$ satellite from wheat and barley

\begin{tabular}{|c|c|c|}
\hline Property & Wheat & Barley \\
\hline $\begin{array}{l}\text { Buoyant density }\left(\mathrm{g} / \mathrm{cm}^{3}\right) \\
\text { neutral } \mathrm{CsCl} \text { native } \\
\text { reannealed } \\
\text { alkaline } \mathrm{Cs} / \mathrm{Cl}\end{array}$ & $\begin{array}{c}1 \cdot 699 \\
1 \cdot 705 \\
1 \cdot 755 / 1 \cdot 740\end{array}$ & $\begin{array}{c}1 \cdot 699 \\
1 \cdot 705 \\
1 \cdot 757 / 1 \cdot 742\end{array}$ \\
\hline $\begin{array}{l}\text { Thermal denaturation } \\
\mathrm{T}_{m}(10 \mathrm{mM} \text { Tris-1 mM EDTA, } \\
\mathrm{pH} 8.4)\end{array}$ & & \\
\hline $\begin{array}{l}\text { native } \\
\text { reannealed }\end{array}$ & $\begin{array}{l}56 \cdot 6^{\circ} \mathrm{C} \\
48 \cdot 8^{\circ} \mathrm{C}\end{array}$ & $\begin{array}{l}56 \cdot 8^{\circ} \mathrm{C} \\
48 \cdot 7^{\circ} \mathrm{C}\end{array}$ \\
\hline \multicolumn{3}{|l|}{$\begin{array}{l}\mathrm{T}_{m} \text { in } 3 \times \mathrm{SSC}-50 \% \text { formamide } \\
\text { of } \mathrm{cRNA}\end{array}$} \\
\hline $\begin{array}{l}\text { to barley satellite melted from } \\
\text { DNA fixed to nitrocellulose } \\
\text { filter }\end{array}$ & $52^{\circ} \mathrm{C}$ & $52^{\circ} \mathrm{C}$ \\
\hline $\begin{array}{l}\mathrm{C}_{0} \mathrm{t}_{\frac{1}{2}} \text { of reassociation in } 0.03 \mathrm{M} \mathrm{Na}^{+} \\
\% \text { of genome (yield on isolation) }\end{array}$ & $\begin{array}{c}0.28 \mathrm{~mol} \mathrm{I}^{-1} \mathrm{sec}^{-1} \\
1.2 \%\end{array}$ & $\begin{array}{c}0.25 \mathrm{~mol} \mathrm{I}^{-1} \mathrm{sec}^{-1} \\
3.8 \%\end{array}$ \\
\hline
\end{tabular}

A comparable indication is given by the comparison of the thermal denaturation profiles of native and reassociated satellite DNA. With either satellite, when the disassociated strands are reannealed in $0.2 \mathrm{M} \mathrm{Na}+$ to $\mathrm{C}_{0} \mathrm{t}$ of 0.25 the melting temperature $\left(\mathrm{T}_{m}\right)$ of the renatured molecules is $8^{\circ}$ below the $\mathrm{T}_{m}$ of the native molecules (table 1 ). The kinetics of reannealing have been examined under stringent ionic and temperature conditions together with the control of a well characterised $D$. melanogaster satellite (the $1.705 \mathrm{~g} / \mathrm{cc}$ satellite) (Brutlag et al., 1977). The $\mathrm{C}_{0} \mathrm{t}_{\frac{1}{2}}$ value (table 1) indicates similar sequence complexities for the wheat and barley satellites and the complexity is of the same magnitude as that of the Drosphila satellite where the repeating sequence is chiefly a 5 base pair unit. These kinetic analyses also showed evidence of sequence heterogeneity in that the total hypochromicity of the native melting profile was never regained upon renaturation.

The identity of physical properties of the wheat and barley satellites is emphasised in homologous and heterologous reassociation profiles. Hybrids were formed between barley satellite ${ }^{3} \mathrm{H}$ cRNA, and either barley or wheat DNA fixed to nitrocellulose filters. The melting temperatures of these hybrids (table 1) were the same.

Two diploid wheat relatives, T. monococcum and Ae. squarrosa, were also found to have small amounts of this satellite DNA (c. 0.1 per cent of the genome) and again the melting profiles of the heterologous hybrids were identical to that of the homologous hybrid.

Satellite DNAs in $\mathrm{Ag}^{+}-\mathrm{Cs}_{2} \mathrm{SO}_{4}$ buoyant density gradients of wheat DNA have been described (Ranjekar et al., 1976; Huguet and Jouanin, 1972). However, the DNAs used in these studies were from commercial wheat varieties and their satellites differ in physical properties from that which we describe in this paper. 

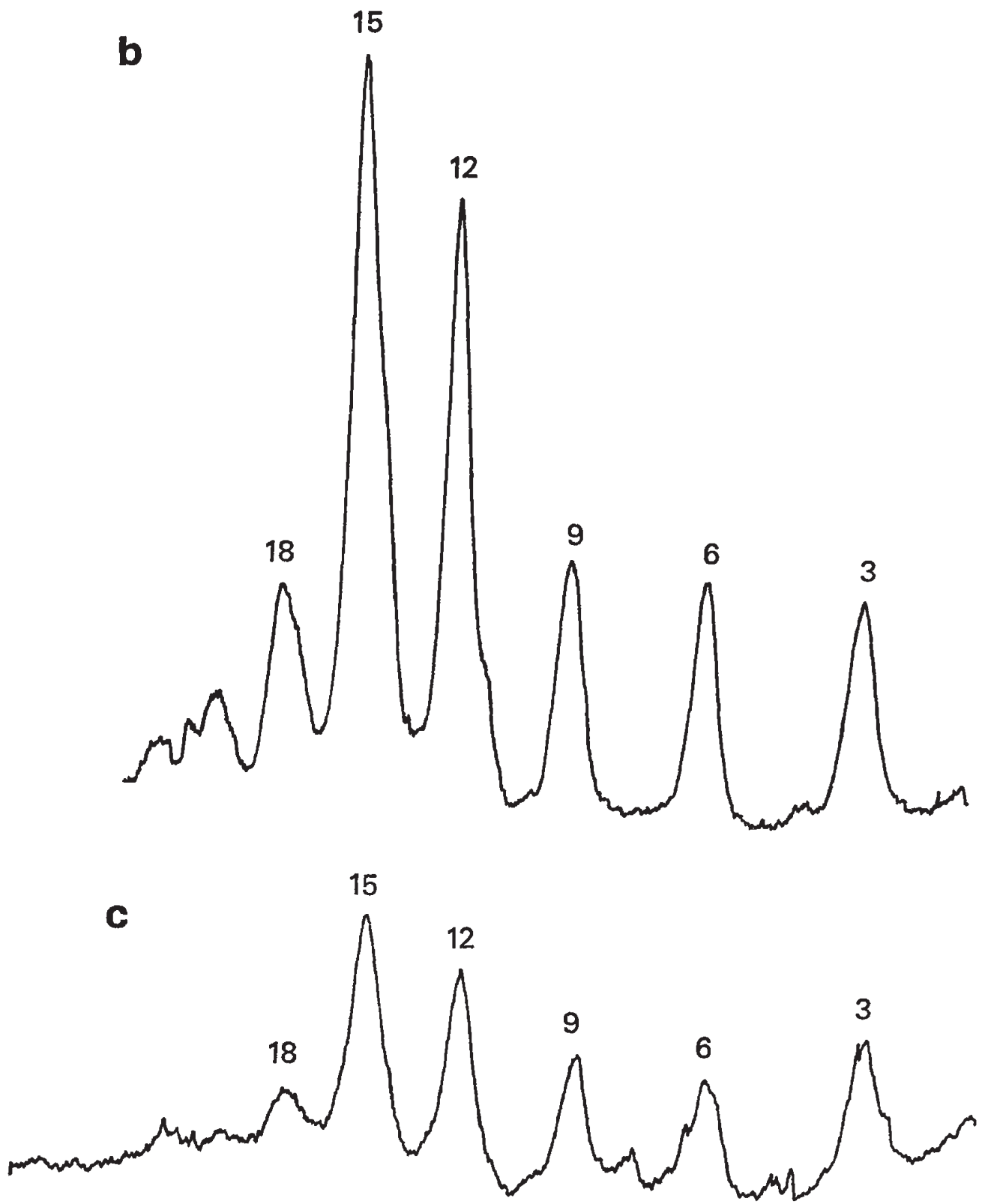

Fig. 2.-(b) Scan of Mbo II digest of wheat satellite DNA nick translated with dTTP ${ }^{32}$. Figures indicate length of segment (base pairs). (c) as (b) only barley satellite. The relative proportions of the various fragment lengths were altered when different radioactive bases were used for labelling. Note that Fig 2(a) faces p. 362. 


\section{(ii) Sequence analysis}

In a survey with a number of restriction enzymes the satellite DNA was shown not to contain any restriction sites for Bam, Pst, EcoRI, Hind III, Hae III, Sal I, Sma I, Hae II or Hha I. However, Mbo II reduced the DNA molecules to a size smaller than $100 \mathrm{bp}$.

The satellite sequences were examined by Mbo II restriction analysis of DNA labelled with ${ }^{32} \mathrm{P}$ by nick translation. The digestion products were analysed by electrophoresis in 20 per cent polyacrylamide- $7 \mathrm{M}$ urea gels, followed by autoradiography (fig. 2). Both DNAs were completely digested to a series of discrete lengths of $3,6,9,12,15,18,21 \ldots$ base pairs (bp). The maximum length of fragments was smaller than $50 \mathrm{bp}$ and in a complete digest 90 per cent of the radioactivity was contained within the $2 \mathrm{l} \mathrm{bp}$ or smaller fragments, indicating a simple repeating sequence. The molar distribution of radioactivity and the molar distribution of these bands are shown in table 2 and give identical patterns for the satellites from the two sequences.

\section{TABLE 2}

Proportion of radioactivity in the various fragments of wheat and barley satellite following digestion with Mbo II and electrophoresis on $7 \mathrm{M}$ urea 20 per cent polyacrylamide gels

Band No. $\begin{gathered}\text { Relative amount } \\ \text { of radioactivity }\end{gathered} \begin{gathered}\text { Integral relative } \\ \text { amount of } \\ \text { radioactivity }\end{gathered} \quad \begin{gathered}\text { Length of } \\ \text { segment (bp) }\end{gathered} \quad$ Molar value

$\alpha^{32} \mathrm{P}$ dTTP nick translation of wheat satellite

$\begin{array}{lllrl}1 & 1 & 1 & 3 & 2 \\ 2 & 1 \cdot 0444 & 1 & 6 & 1 \\ 3 & 1 \cdot 0637 & 1 & 9 & 0 \cdot 67 \\ 4 & 2 \cdot 8127 & 3 & 12 & 1 \cdot 5 \\ 5 & 4 \cdot 0564 & 4 & 15 & 1 \cdot 6 \\ 6 & 0 \cdot 9200 & 1 & 18 & 0 \cdot 3 \\ 7 & 0 \cdot 3984 & 0 \cdot 5 & 21 & 0 \cdot 1\end{array}$

$\alpha^{32} \mathrm{P}$ dTTP and $\alpha^{32} \mathrm{P}$ dCTP nick translation of wheat satellite

$\begin{array}{lllrl}1 & 1 & 1 & 3 & 2 \\ 2 & 1.0175 & 1 & 6 & 1 \\ 3 & 1.0413 & 1 & 9 & 0.67 \\ 4 & 3.6345 & 3.5 & 12 & 1 \cdot 75 \\ 5 & 2 \cdot 3648 & 2 \cdot 5 & 15 & 1 \\ 6 & 1.5271 & 1.5 & 18 & 0.5 \\ 7 & 0.9176 & 1 & 21 & 0 \cdot 3\end{array}$

${ }^{32} \mathrm{P}$ dTTP nick translation of barley satellite

$\begin{array}{lllrl}1 & 1 \cdot 0 & 1 & 3 & 2 \\ 2 & 0.85 & 1 & 6 & 1 \\ 3 & 0.93 & 1 & 9 & 0 \cdot 67 \\ 4 & 2 \cdot 71 & 3 & 12 & 1 \cdot 5 \\ 5 & 3 \cdot 71 & 4 & 15 & 1 \cdot 6 \\ 6 & 0 \cdot 6 & 1 & 18 & 0 \cdot 3 \\ 7 & 0.3 & 0.5 & 21 & 0 \cdot 1\end{array}$

Wheat and barley satellites were labelled by nick translation using $\alpha^{32} \mathrm{P}$ deoxynucleoside triphosphates. The DNAs were digested with Mbo II, electrophoresed and autoradiographed. The films were scanned with a densitometer and the proportion of radioactivity in each band determined from the area under the peak. 
Since the Mbo II enzyme recognises the sequence 5'GAAGA3' $^{\text {'GTTCT5', and a }}$ substantial proportion of radioactivity is in 3 base pair fragments, much of

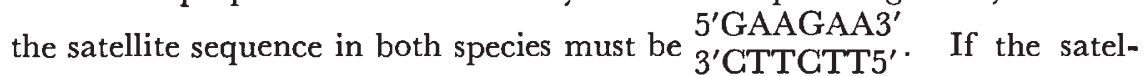
lite DNA is nick translated with both dCTP32 and dTTP ${ }^{32}$ and digested with Mbo II enzyme, two classes of trinucleotides can be isolated by chromatography on PEI plates $-\mathrm{T}_{2} \mathrm{C}$ and $\mathrm{C}_{2} \mathrm{~T}$ in the ratio $9: 1$. This suggests a repeat of $30 \mathrm{bp}(\mathrm{GAA})_{9}(\mathrm{GAG})_{1}$. However, the uncertainties of the quantitative characteristics of Mbo II action and the likelihood of there being different but related arrays within the satellite population (Brutlag and Peacock, 1975) do not permit the specification of a unique repeat unit. We can formulate the satellite composition as $(\mathrm{GAA})_{m}(\mathrm{GAG})_{n}$ where $\mathrm{m}$ and $\mathrm{n}$ may have different values in different arrays. Confirmation of this general formula comes from analysis of the nucleotide composition of the digests of the cRNA copies of the separated strands (tables 3 and 4). The expected base complementarity of the cRNAs prepared from the two strands was not observed (table 3 ) and we conclude that the $E$. coli RNA holopolymerase preferentially copied certain regions of the template; nevertheless the data for the two strands did approach complementarity.

\section{TABLE 3}

Base composition of $c R N A$ copies of separated strands of the wheat silver satellite $D N A$

$\begin{array}{ccc}\text { Base } & \text { Heavy strand \% } & \text { Light strand \% } \\ \text { C } & 10 \cdot 4 & 22 \cdot 6 \\ \text { A } & 42 \cdot 0 & 22 \cdot 6 \\ \text { G } & 31 \cdot 4 & 17 \cdot 9 \\ \text { U } & 16 \cdot 2 & 36 \cdot 9\end{array}$

Base composition of cRNAs prepared from separated strands of the wheat satellite DNA. The compositions are expressed as the percentage counts in each of the four nucleoside monophosphates after hydrolysis of ${ }^{32} \mathrm{P}$ labelled cRNAs fractioned by high voltage electrophoresis (Brownlee, 1972).

Digestion of the RNA copies of the separated strands with pancreatic RNAse (table 4) gives CMP and UMP as the major digestion products. A substantial proportion of radioactivity remains at the origin in each case. The base composition of this material shows it to be polypurine. These results indicate that there are long regions containing adjacent adenine and guanine residues and other long regions containing adjacent cytosine and uracil. $\mathrm{T}_{1}$ digests (table 5 ) of the heavy strand yield a complementary result with the major portion of the RNA being digested (only 26 per cent at the origin) and the principal chromatographic spots, other than the origin, are $\mathrm{G}, \mathrm{AG}$ and $\mathrm{AAG}$, with 40 per cent of the radioactivity in $\mathrm{AAG}$, and with $A G$ and $G$ being present in equivalent amounts. Hence the sequence of the RNA complementary to the heavy strand agrees with the general formulation from restriction enzyme digests, namely (GAA) ${ }_{m}$ $(\mathrm{GAG})_{n}$. The RNA digestions alone suggest an average composition of $(\mathrm{GAA})_{3}(\mathrm{GAG})_{1}$ but the Mbo II data clearly show that this cannot be the repeating unit. The RNA sequencing data show the presence of additional

$44 / 3-\mathrm{E}$ 


\section{Table 4}

Proportion of counts in various digestion products following pancreatic

$$
R \mathcal{N A a s e} \text { treatment }
$$

Results of complete pancreatic RNAase digestion of uniformly ${ }^{32} \mathrm{P}$ labelled cRNAs made from purified light and heavy strands as templates. The values represent the percentage radioactivity in each reaction after two dimensional PE I chromatography. Values in brackets are the molar ratios for oligonucleotides.

\begin{tabular}{|c|c|c|c|}
\hline & & Heavy strand cRNA & Light strand cRNA \\
\hline & $-\mathrm{C}$ & $5.6(100)$ & $16 \cdot 5(100)$ \\
\hline & $\mathrm{AC}$ & $0.92(8)$ & $3 \cdot 3(10)$ \\
\hline & $\mathrm{A}_{2} \mathrm{C}$ & $0.59(4)$ & $1 \cdot 3(3)$ \\
\hline & $\mathrm{A}_{3} \mathrm{C}$ & $0 \cdot 13(0.5)$ & $0.6(0.9)$ \\
\hline & $\mathrm{U}$ & $7 \cdot 4(100)$ & $21 \cdot 8(100)$ \\
\hline & $\mathrm{AU}$ & $1 \cdot 3(9)$ & $4 \cdot 6(11)$ \\
\hline & $\mathrm{A}_{2} \mathrm{U}$ & $0.59(3)$ & $1.8(3)$ \\
\hline & $\mathrm{A}_{3} \mathrm{U}$ & $0.26(0.9)$ & $0.9(0.9)$ \\
\hline & $(\mathrm{UC}) *$ & $2 \cdot 17$ & $\longrightarrow$ \\
\hline & GC & 0.85 & $3 \cdot 7$ \\
\hline & $(\mathrm{AG}) \mathrm{C}$ & $0 \cdot 66$ & $1 \cdot 8$ \\
\hline & $\left(\mathrm{A}_{2} \mathrm{G}\right) \mathrm{C}$ & $0 \cdot 33$ & 0.9 \\
\hline & GU & $1 \cdot 1$ & $4 \cdot 0$ \\
\hline & $(\mathrm{AG}) \mathrm{U}$ & 0.99 & $2 \cdot 5$ \\
\hline longer & oligonucleotides & $7 \cdot 8$ & $5 \cdot 9$ \\
\hline & origin & $69 \cdot 4$ & $27 \cdot 7$ \\
\hline
\end{tabular}

\section{TABLE 5}

Proportion of counts in various digestion products following ribonucleas treatment. Results of complete $T_{1} R \mathcal{N A \text { ase digestion of uniformly } { } ^ { 3 2 } \mathrm { I }}$ labelled $c R$ NAs made from purified light and heavy strands as templates Values are as in legend to table 4

$\begin{array}{lcc} & \text { Heavy strand cRNA } & \text { Light strand cRNA } \\ \mathrm{A} & 3 \cdot 1 & \\ \mathrm{G} & 5 \cdot 5(4) & 7 \cdot 2(10) \\ \mathrm{AG} & 10 \cdot 5(4) & 11 \cdot 3(8) \\ \mathrm{A}_{2} \mathrm{G} & 41 \cdot 0(10) & 14.7(7) \\ \mathrm{A}_{3} \mathrm{G} & - & 0 \cdot 6 \\ \mathrm{CG} & - & 1 \cdot 7 \\ (\mathrm{AC}) \mathrm{G} & - & 1 \cdot 5 \\ \left(\mathrm{~A}_{2} \mathrm{C}\right) \mathrm{G} & - & 0.4 \\ \text { UG } & & 2 \cdot 1 \\ \text { longer oligonucleotides } & 13.9 & 14 \cdot 7 \\ \text { Origin } & 26.0 & 45.6\end{array}$

minor components (table 4) indicating heterogeneity of the satellite sequence. A value of about 8 per cent sequence mismatching is indicated by the buoyant density increase seen in reannealed DNA.

The light strand cRNA data are difficult to analyse fully since the $T_{1}$ and pancreatic digests are not complementary. However, it is probable that each strand used as template for cRNA synthesis has long polypurine regions and long arrays of polypyrimidines. 


\section{(iii) Length of polypyrimidine regions}

The lengths of polypyrimidine tracts in the DNA have been estimated using $\mathrm{cRNAs}$ generated in reactions including only radioactively labelled ATP and GTP. The exclusion of the other two triphosphates permits polypyrimidine sequences to act selectively as templates. The lengths of these cRNAs were determined in 4.8 per cent formamide acrylamide gels. The transcripts from the DNA heavy and light strand templates had mean lengths of 640 and 890 bases respectively. Transcripts were also synthesised using radioactive ATP and GTP and unlabelled UTP and CTP, and examined by alkaline hydrolysis. They provided essentially a nearest neighbour analysis for the adenine and guanine bases, and showed 97.7 per cent of the neighbours of adenine and guanine residues in the heavy strand cRNA are other adenines and guanines. An estimate of the maximum length of the pyrimidine tracts can be derived from the length of the cRNA products. Assuming that transcription is initiated at random and that only the predominantly pyrimidine tracts act as templates, then the mean length of the cRNA products will be one half of the length of the template. Thus the pyrimidine rich tracts may be as long as 1300 to 1800 nucleotides in each of the strands of the satellite.

\section{(iv) Organisation of the satellite $D \mathcal{N A}$ in the genome}

In barley the DNA content per haploid genome is $5 \cdot 1 \times 10^{9} \mathrm{bp}$ (Bennett and Smith, 1976) and as 4 per cent of this is satellite DNA $\left(2 \cdot 0 \times 10^{8} \mathrm{bp}\right)$ then there must be approximately $2 \times 10^{7}$ copies per genome of the $12 \mathrm{bp}$ repeating sequence. In wheat the calculation $\left(15.3 \times 10^{6} \mathrm{~kb}\right.$, Bennett and Smith, 1976) for the size of the hexaploid genome (of which 1.2 per cent is satellite) gives a similar number of opoies per hexaploid genome.

Since satellite DNA molecules of average size $20 \mathrm{~kb}$ have been isolated with some molecules being as long as $150 \mathrm{~kb}$ we conclude the satellite DNA is predominantly organised in the genome in uninterrupted tracts. This is supported by the fact that the yield of satellite DNA in buoyant density gradients is not increased by shearing total DNA from an average length of $20 \mathrm{~kb}$ down to $5 \mathrm{~kb}$ indicating lack of interspersion of other sequences.

Most satellite sequences are present in the genome of long tracts but hybridisation of satellite cRNA across a $\mathrm{Ag}^{+} / \mathrm{Cs}_{2} \mathrm{SO}_{4}$ gradient of total wheat DNA show a small proportion of satellite sequences must be attached to other sequences (fig. 3). A similar pattern was obtained with barley DNA. The technique grossly underestimates the proportion of sequences in the satellite peak, so quantitative estimates of the proportion of DNA in the satellite peak and in density regions intermediate between the satellite and main band have not been obtained. The minor peaks in the satellite region are reproducible and possibly indicate the existence of sequence variants in the satellite which are fractionated by the conditions of the gradient.

\section{(v) Chromosomal locations}

Consistent with an organisation of the majority of satellite sequences in long arrays, in situ hybridisation of ${ }^{3} \mathrm{H}$ RNA complementary to the satellite showed major chromosomal locations in the genomes of wheat and barley. 


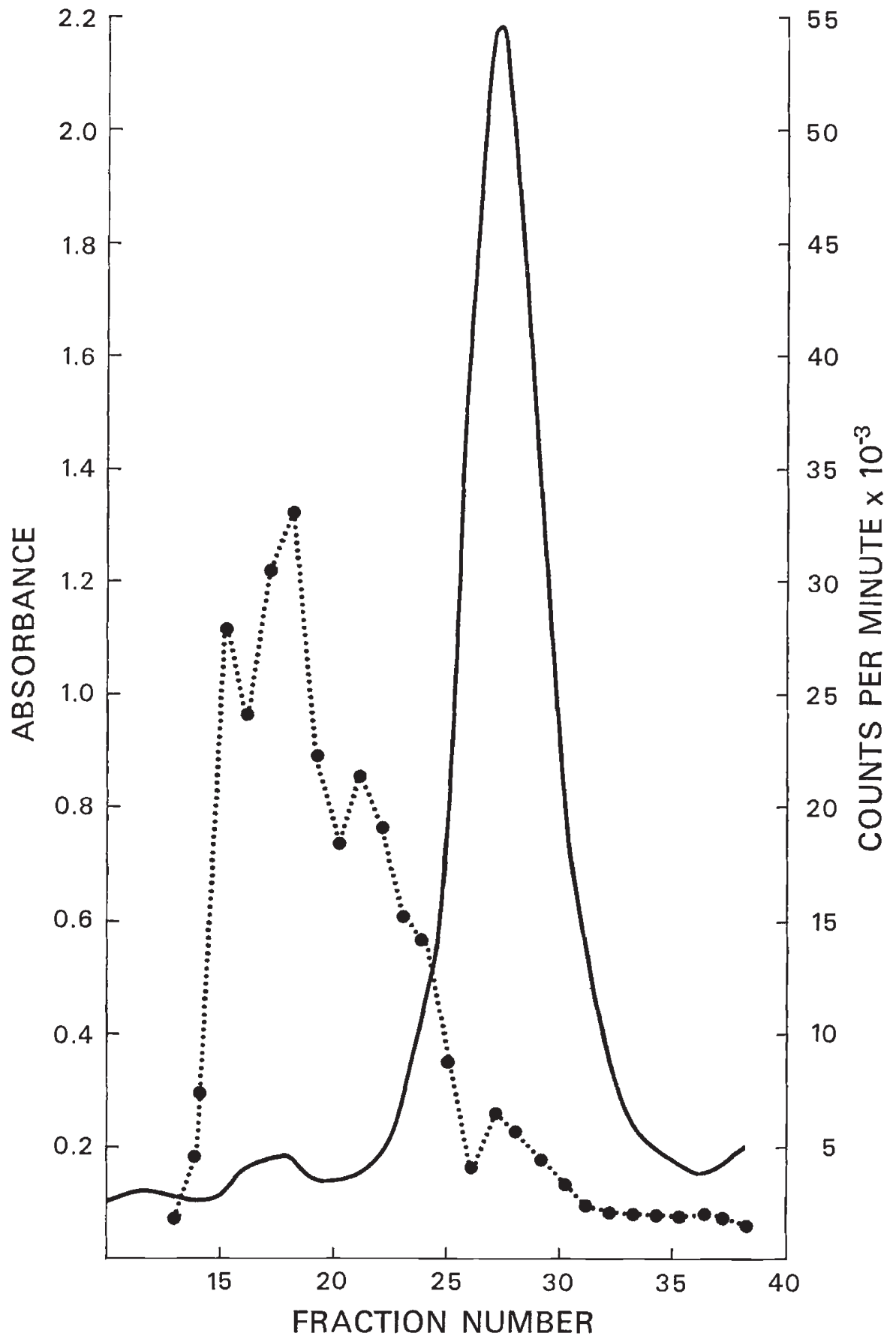

FIG. 3.-Hybridisation across a $\mathrm{Ag}^{+} / \mathrm{Cs}_{2} \mathrm{SO}_{4}$ gradient with a ${ }^{3} \mathrm{H}$ RNA complementary to the silver satellite of wheat. Total wheat DNA was centrifuged to equilibrium in a $\mathrm{Ag}^{+} /$ $\mathrm{Cs}_{2} \mathrm{SO}_{4}$ gradient $\mathrm{R}_{\mathrm{F}}=0.125$ and fractionated by collection from the bottom. Aliquots of each fraction were denatured, neutralised, fixed to nitrocellulose filters, baked and hybridised to the ${ }^{3} \mathrm{H}$ RNA. $\cdots \cdot$ radioactivity; - absorbance $260 \mathrm{~nm}$. 


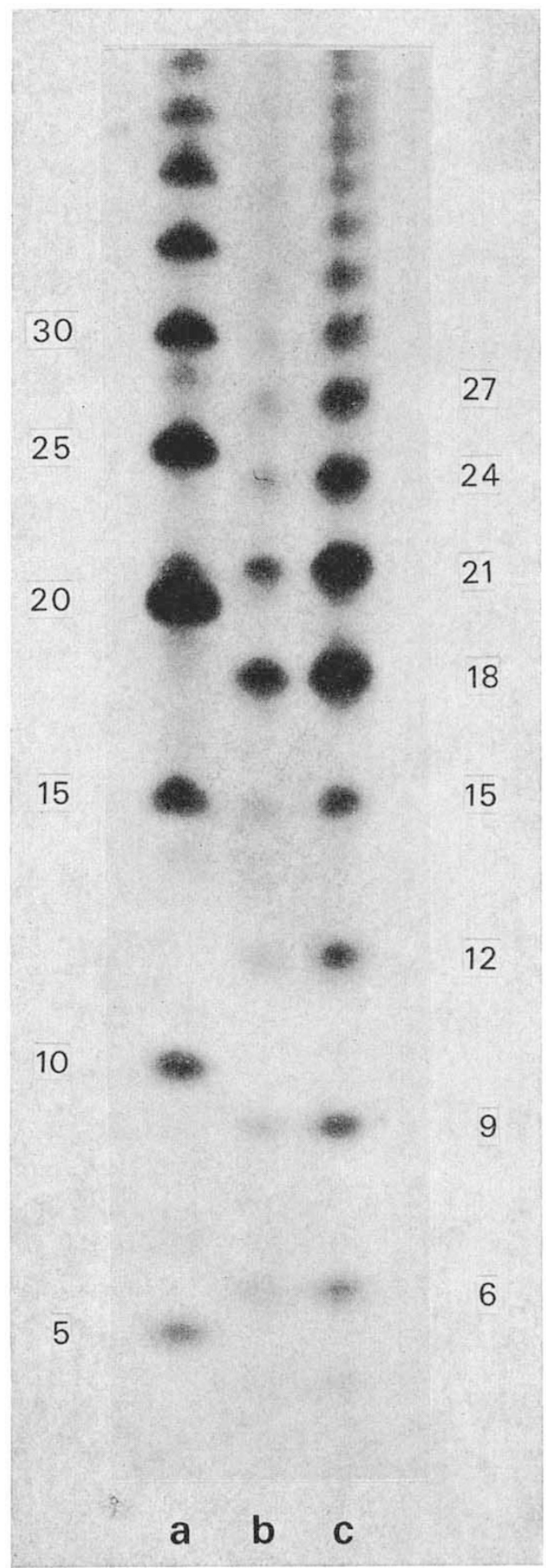

FIG. 2.-(a) Autoradiograph of (a) Drosophila melanogaster $1.705 \mathrm{~g} / \mathrm{cc}$ (b) barley and (c) wheat satellite DNAs, all nick translated with dCTP $^{32}$ digested with Mbo II and electrophoresed on 20 per cent acrylamide-7M urea gels. The D. melanogaster satellite DNA was included to provide size markers (see Materials and Methods). Note that Fig. 2(b) is on p. 357 . 


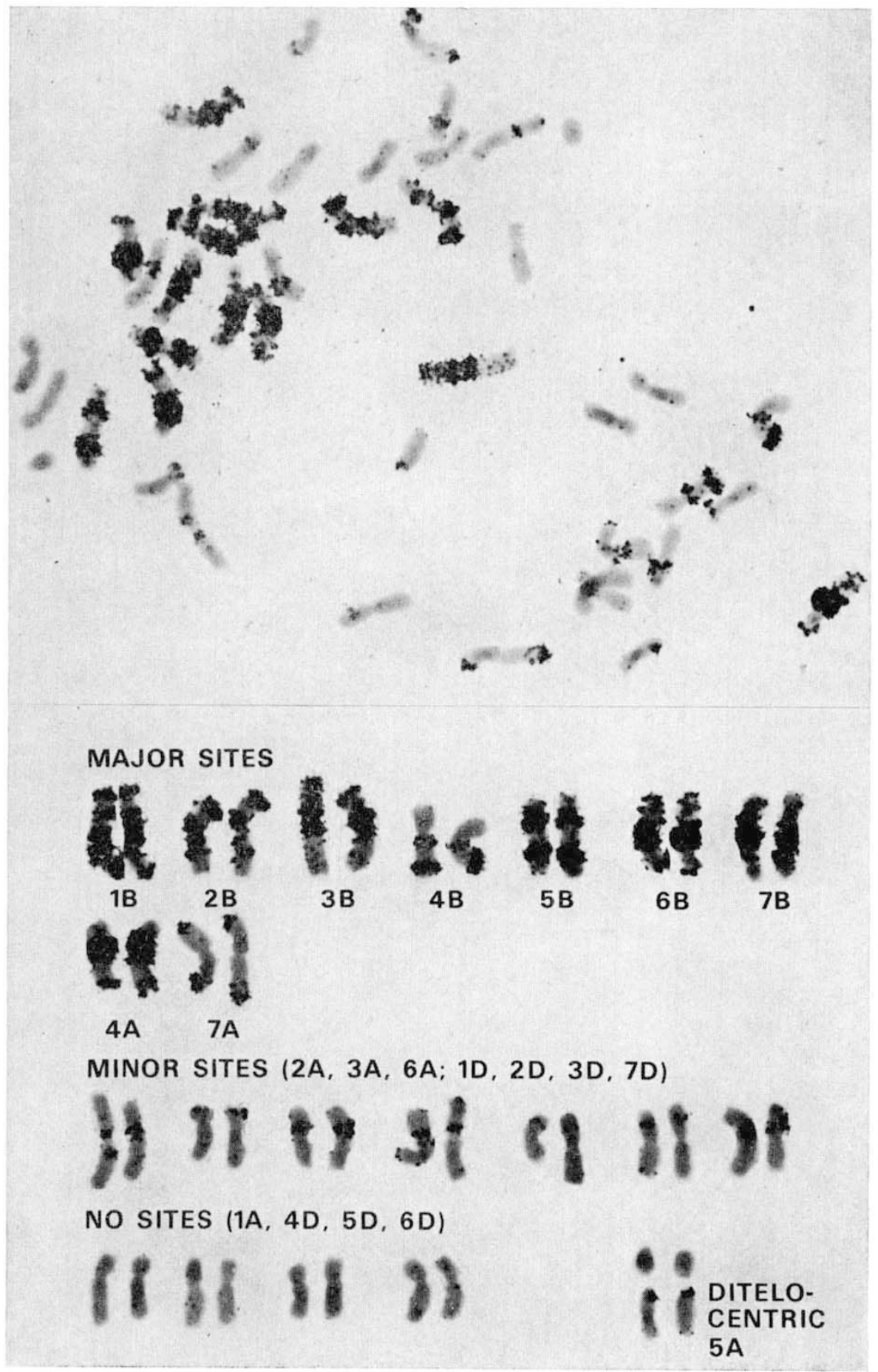

FIG. 4.-Localisation of the silver satellite in the wheat genome. The top frame shows a metaphase spread of hexaploid wheat which has chromosome $5 \mathrm{~A}$ present in the double ditelocentric form. In situ hybridisation was carried out as described in the text and exposure was for one month, sufficient to visualise the minor sites. Beneath this, the karyotype from the in situ hybridisation is shown, the chromosomal sites having been identified using a series of double ditelo tester stocks. A diagram of the sites seen on the individual chromosomes is also shown. 

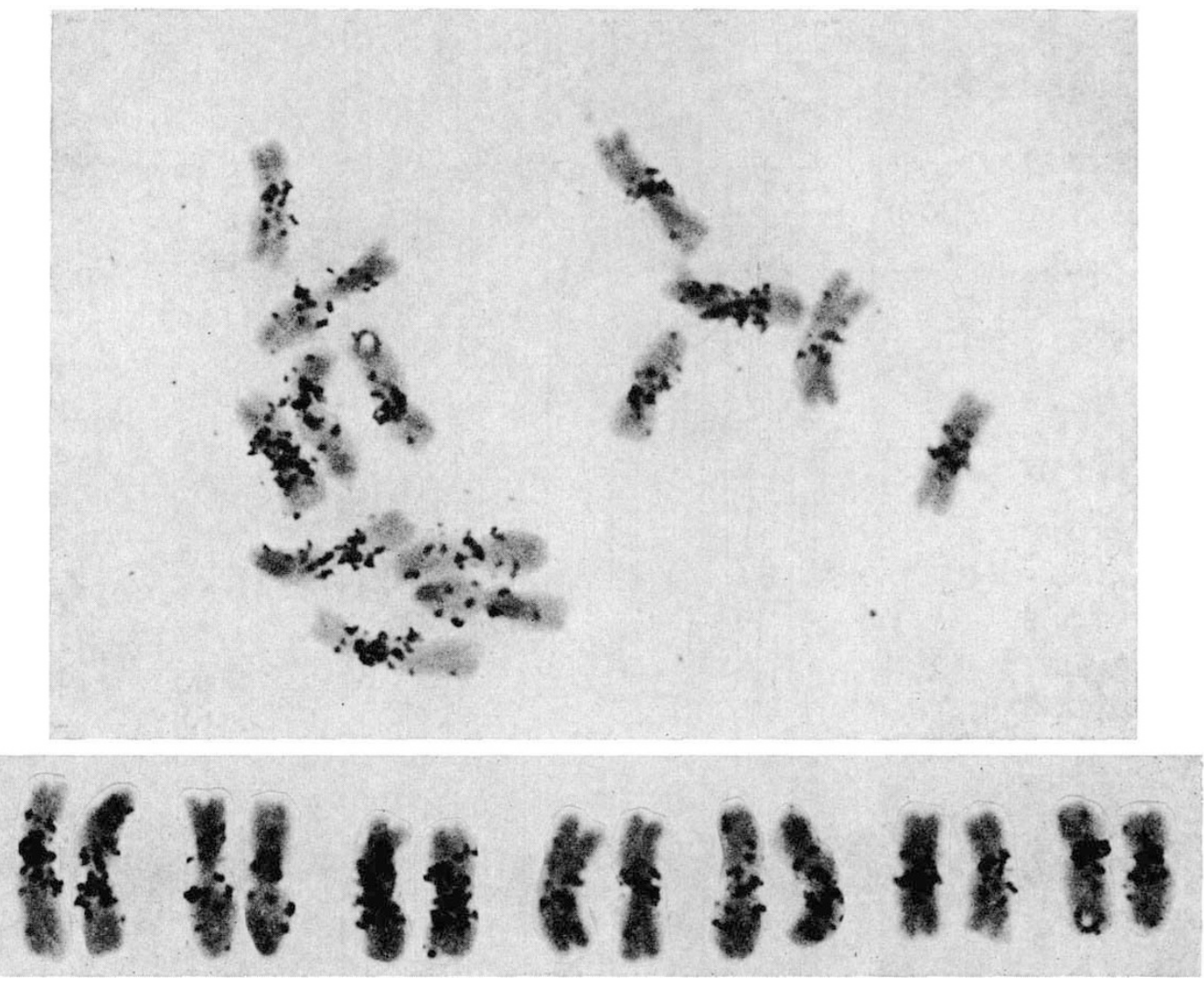

Fig. 5.-Localisation of the silver satellite in the barley genome. The top picture shows a metaphase spread of barley followed by in situ hybridisation to a cRNA to the satellite DNA. The lower picture shows a karyotype from this spread. 
Plate III
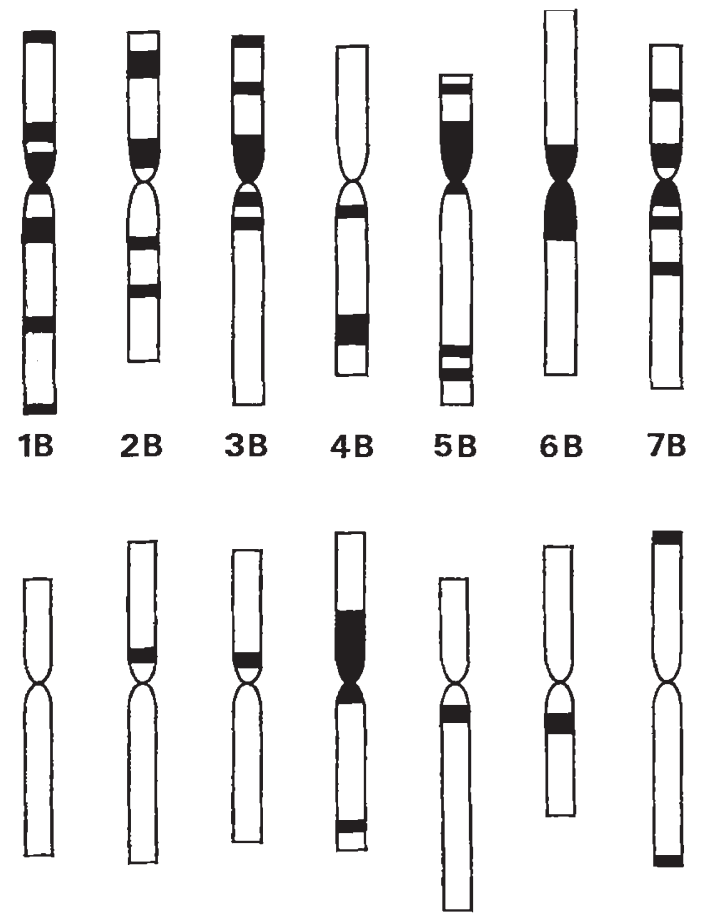

$\begin{array}{lllllll}1 A & 2 A & 3 A & 4 A & 5 A & 6 A & 7 A\end{array}$

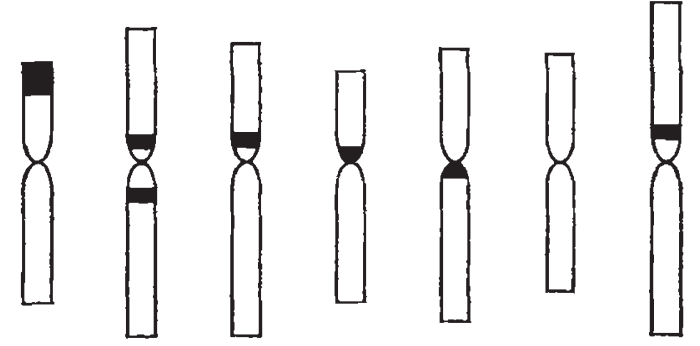

1D 2D 3D $\quad 4 D \quad 5 D \quad 6 D \quad 7 D$

Fig. 4. 
The sites are interstitial and telomeric as well as peri-centromeric. The in situ hybridisations to root tip metaphase chromosomes were carried out at $45^{\circ}, 10^{\circ}$ below the $\mathrm{T}_{m}$ of the cRNA-DNA hybrids formed on nitrocellulose filters. These stringent conditions ensured that only specific hybrids were formed in the in situ experiments.

The chromosomal locations of the satellite sequences are shown in fig. 4 (wheat) and fig. 5 (barley). In wheat the identities of the nine chromosomes which showed distinctive major blocks of the satellite were determined using ditelocentric tester stocks (Sears, 1963). The use of these stocks, each of which contains a chromosome broken at the centromere, allows unambiguous identification of the sites. The major sites are on the seven $\mathrm{B}$ genome chromosomes and chromosomes 4A and 7A (fig. 4). This pattern of sites is the same as that produced by a rapidly renaturing fraction (Gerlach and Peacock, 1979); presumably the individual chromosomal sites are also the same. No major sites were present on other A or D genome chromosomes; however, longer exposures $(\times 10)$ showed the presence of minor sites on both $\mathrm{A}$ and $\mathrm{D}$ genome chromosomes. The ditelocentric tester stocks have also enabled identification of these sites. In barley (fig. 5), all chromosomes have pericentromeric locations of the satellite with two pairs having a much larger amount of label than the others.

\section{Discussion}

The finding that the same highly repeated DNA sequence is present in barley, hexaploid wheat, Ae. squarrosa, and T. monococcum, but in vastly different amounts, parallels a similar observation in animal species where, over evolutionary periods of time, various satellite sequences are conserved relative to other sequences in the genome but can show extreme modulation in the amount of the sequence (Salser et al., 1976; Lohe, 1977; Peacock et al., 1977). Renaturation studies by Bendich and McCarthy (1970) allow us to compare the conservation of the satellite sequence with that of middle and unique sequence DNAs. They found that in wheat and barley, genera in different taxonomic subtribes, there is more than 4 per cent mismatching of heterologous hybrids of middle repeated and unique sequence DNA. This contrasts with our findings of no sequence change in the satellite, as assessed by its extensive similarities in sequence and physical properties in wheat and barley.

Although the sequence of the satellite DNA may have been conserved, its chromosomal locations appear to vary considerably between wheat and barley. In barley, the localisation of the satellite is principally pericentromeric whereas in wheat it is partly pericentromeric, partly interstitial and in some cases telomeric. This may be a consequence of extensive amplification or reduction of satellite sequences at particular locations, similar to the differences seen between $D$. melanogaster and $D$. simulans (Lohe, 1977). The recent availability of addition lines of barley chromosomes to the wheat genome (Islam et al., 1978), should enable us to determine whether there have been extensive chromosomal rearrangements between the two species causing the differences in satellite locations.

Heterochromatin defined by $\mathrm{N}$ banding (Gerlach, 1977) showed a pattern identical to that obtained by in situ hybridisation of the satellite. 
On the other hand when C banding (Gill and Kimber, 1974) was used to define heterochromatin, there was a general, but not exact, correspondence to the in situ hybridisation pattern of the satellite DNA. Both techniques show the wheat B genome chromosomes to contain centromeric as well as interstitial bands of heterochromatin. An example of the differences between the $\mathrm{C}$ banding and in situ patterns is that $\mathrm{C}$ banding shows an interstitial band in the short arm and centromeric heterochromatin on chromosome 7A whereas in situ hybridisation localises the satellite DNA at the telomeres of this chromosome. In barley, C banding, in the "York" cultivar (Linde-Laursen, 1975) shows mostly pericentric heterochromatin with a few interstitial bands, and the satellite DNA localisation in the cultivar "Clipper", characterised in the present study, displays a similar but not identical pattern. The differences in this instance may be due to the use of different cultivars since $\mathrm{C}$ banding patterns do vary between cultivars of barley (Noda and Kasha, 1977).

\section{Origin of hexaploid wheat}

The distribution of the satellite sequences over the three genomes of hexaploid wheat (A, B, D) has enabled us to evaluate which of the suggested donors could have contributed these genomes to modern wheat.

The $\mathrm{D}$ genome has only minor sites so that any candidate species for the D genome donor might be expected to contain only small amounts of this particular highly repeated DNA sequence. Consistent with this, chromosomes of Ae. squarrosa, the accepted donor of the D genome to hexaploid wheat (McFadden and Sears, 1946), contain no major sites. The situation of the A and B genomes is more complex (Gerlach et al., 1978). Examination of a number of proposed $B$ genome donors shows that none has a satellite distribution identical to the pattern observed for the B genome in hexaploid wheat. Chromosomes with satellite distribution resembling chromosomes 5B, 3B and 2B have been observed in lines of Ae. longissima making this a more likely candidate for the $\mathrm{B}$ genome donor than the other species examined-Ae. mutica, Ae. bicornis, Ae. sharonensis, Ae. speltoides, Triticum urartu. Nevertheless, it may be that the B genome in hexaploid wheat did not arise from a single species, but has had a more complex origin.

None of the proposed A genome donors of hexaploid wheat has a satellite distribution pattern identical to that of the A genome in hexaploid wheat. In particular, the major satellite blocks present on chromosomes $4 \mathrm{~A}$ and $7 \mathrm{~A}$ are not present in $\mathcal{T}$. monococcum or $\mathcal{T}$. boeticum. Chromosome $4 \mathrm{~A}$ is peculiar in a number of its properties. For example, it is the only A genome chromosome which will not pair with chromosomes of a presumptive AA diploid T. urartu (Chapman et al., 1976) and it stands apart from the other group IV homoeologues $4 \mathrm{~B}$ and $4 \mathrm{D}$, in that it bears unique fertility factors (Sears, 1966). It is possible that chromosome $4 \mathrm{~A}$ has its ancestry through introgression of $\mathrm{B}$ genome chromosomes or from some other donor species.

Acknowledgments. - This work was carried out when W. L. G. was the recipient of a Rothmans Fellowship. The authors are grateful to Janice Norman, Yvonne Hort and Georgina Koci for expert technical assistance, to Dr P. Whitfeld for RNA markers, and Drs K. Shepherd and B. Dunstone for seed. 


\section{REFERENCES}

BENDICH, A. J., AND MCCARTHY, B. J. 1970. DNA comparisons among barley, oats, rye and wheat. Genetics 65, 545-565.

BENNETT, M. D., AND sMith, J. B. 1976. Nuclear DNA amounts in angiosperms. Phil. Trans. Royal Soc. (Lond.), B. Biological Sciences 274, 227-274.

BIRNSTIEL, M. L., SELls, B. H., AND PURDOM, I. F. 1972. Kinetic complexity of RNA molecules. 7. Mol. Biol., 63, 21-39.

Brownlee, G. G. 1972. Determination of sequences in RNA, eds. T. S. Work and E. Work. North Holland Publishing Co., Amsterdam.

BRUTLAG, D. L., CARLSON, M., FRY, K., AND HSIEH, T. s. 1977. DNA sequence organization in Drosophila heterochromatin. Cold Spring Harbor Symp. Quant. Biol., 42, 1137-1146.

BRUTLAG, D. L., AND PEACOCK, w. J. 1975. Sequences of highly repeated DNA in Drosophila melanogaster. In: The Eukaryote Chromosome. Aust. Nat. Univ. Press, Canberra.

BURGESS, D. R., AND JENDRISAK, J. J. 1975. A procedure for the rapid, large scale purification of Escherichia coli DNA-dependent RNA polymerase involving polymin P precipitation and DNA cellulose chromatography. Biochemistry, 14, 4634.

CHAPMAN, v., MILlER, T. E., AND RILEY, R. (1976). Equivalence of the A genome of bread wheat with that of Triticum urartu. Genet. Res. Camb., 27, 69-76.

ENDow, s. A. 1977. Analysis of Drosophila melanogaster satellite IV with restriction endonuclease Mbo II. 7. Mol. Biol., 114, 441-449.

FRY, K., AND SALSER, w. 1977. Nucleotide sequences of $\mathrm{HS} \alpha$ satellite from kangaroo rat Dipodomys ordii and characterization of similar sequences in other rodents. Cell, 12, 1069-1084.

Gall, J. G., ANd Atherton, D. D. 1974. Satellite DNA sequences in D. virilis. J. Mol. Biol., 85, 633-664.

GElinAs, R. E., MYERs, D. A., AND ROBERTS, R. J. 1977. Two sequence-specific endonucleases from Moraxella bovis. J. Mol. Biol., 114, 169-179.

GERLACH, w. L. 1977. N-banded karyotypes of wheat species. Chromosoma, 62, 49-56.

GERLACH, w. L., APPELS, R., DENNIS, E. s., AND PEACOCK, w. J. 1978. Evolution and analysis of wheat genomes using highly repeated DNA sequences. Proc. 5th Int. Wheat Genet. Symp., 1, 81-91.

GERLACH, w. L., AND PEACOCK, w. J. 1979. Chromosomal locations of highly repeated DNA sequences in wheat. Heredity (in press).

GILl, B. s., AND KImber, G. 1974. Giemsa C-banding and the evolution of wheat. Proc. Nat. Acad. Sci. USA, 71, 4086-4090.

GRIFFIN, B. E., AND MIRZABEKov, A. D. 1972. 5S RNA conformation studies of the partial $\mathrm{T}_{1}$ ribonuclease digestion by gel electrophoresis and two dimensional thin layer chromatography. 7. Mol. Biol., 72, 633-643.

HENNIG, W., AND WALKER, P. M. B. 1970. Variations in the DNA from two rodent families (Cricetiaea and Muridae). Nature, 225, 915-919.

Huguet, T., AND JouAnin, L. 1972. Wheat DNA : Study of the heavy satellite in $\mathrm{Ag}^{+}$. $\mathrm{Cs}_{2} \mathrm{SO}_{4}$ density gradient. Biochem. Biophys. Res. Comm., 46, 1169-1174.

ISLAM, A. K. M. R., SHEPHERD, K. W., AND SPARROW, D. H. B. 1978. Wheat-barley hybrids and addition lines. Proc. 5th Int. Wheat Genet. Symp., 1, 365-371.

LINDE-LAURSEN, I. 1975. Giemsa C-banding of the chromosomes of "Emir" barley. Hereditas, 81, 285-289.

LOHE, A. R. 1977. Highly repeated DNA in Drosophila simulans: chromosomal organization and evolutionary stability. Ph.D. Thesis, Australian National University.

maXam, A. M., AND Gilbert, w. 1977. A new method for sequencing DNA. Proc. Nat. Acad. Sci. USA, 74, 560-564.

MCFADDEN, E. S., AND SEARs, E. R. 1946. The origin of Triticum spelta and its free threshing hexaploid derivatives. F. Hered., 37, 107-116.

NODA, K., AND KASHA, K. J. 1977. Barley chromosome identification with the C banding. Giemsa stain technique. Barley Genetics Newsletter 1977, 47-50.

PEAcock, w. J., BRutlag, D., Goldring, E., APPEls, R., HiNTON, C. N., AND Lindsley, D. L. 1973. The organization of highly repeated DNA sequences in Drosophila melanogaster chromosomes. Cold Spring Harbor Symp. Quant. Biol., 38, 405-416.

PEACOCK, w. J., APPels, R., DUNSmuir, P., LOHE, A. R., AND GERlach, w. L. 1976. Highly, repeated DNA sequences: chromosomal localization and evolutionary conservation. In: International Cell Biology, eds. B. R. Brinkley and K. R. Porter. Rockefeller University Press, pp. 494-506. 
PeACOCK, W. J., LOHE, A. R., Gerlach, W. L., DUNSMUiR, P., DENNIS, E. S., AND APPELS, R. 1977. Fine structure and evolution of DNA in heterochromatin. Cold Spring Harbor Symp. Quant. Biol., 42, 1121-1135.

Ranjekar, P. K., Palotta, D., AND lafontaine, J. G. 1976. Analysis of the genome of plants. II. Characterization of repetitive DNA in barley and wheat. Biochim. Biophys. Acta, 425, 30-40.

RIGBY, P. W. J., DIECKMANN, M., RHODES, C., AND BERG, P. 1976. Labelling deoxyribonucleic acid to high specific activity in vitro by nick translation with DNA polymerase I. $\mathcal{J}$. Mol. Biol., 113, 237-251.

SALSER, W., BOWENS, S., BROWN, D., EL ADLI F., FEDOROFF, N., FRY, K., HEINDELL, H., PADDOCK, G., POON, R., WALlACE, B., AND Whitcome, P. 1976. Investigation of the organization of mammalian chromosomes at the DNA sequence level. Fed. Proc., 35, 23-35.

SEARS, E. R. 1963. Ghromosome mapping with the aid of telocentrics. Proc. 2nd Int. Wheat Genetics Symp., published in Hereditas, Suppl. Vol. 2 (1966).

SEARS, E. R. 1966. Nullisomic-tetrasonic combinations in hexaploid wheat. In "Chromosome Manipulations and Plant Genetics", eds. R. Riley and K. R. Lewis. Oliver and Boyd, Edinburgh, 1966.

SINGH, L., PURDOM, I. F., AND JONEs, K. W. 1977. Effect of different denaturing agents on the detectability of specific DNA sequences of various base composition by in situ hybridization. Chromosoma (Berl.), 60, 377-389.

SOUTHERN, E. M. 1970. Base sequence and evolution of guinea pig $\alpha$ satellite DNA. Nature, 227, 794-798.

symons, R. H. 1974. Synthesis of $\alpha^{32} \mathrm{P}$ ribo- and deoxyribonucleoside triphosphates. Methods in Enzymology, 29, 102-115.

WAlker, P. M. B. 1968. How different are the DNAs from related animals. Nature (Lond.), $219,228-232$. 